\title{
Investigating Asynchronous Online Communication: A Connected Stance Revealed
}

\author{
Susan J Wegmann \\ Baptist College of Florida
}

Joyce K. McCauley

Sam Houston State University

\begin{abstract}
This research project explores the effects of altering the structure of discussion board formats to increase student engagement and participation. This paper will present the findings of a two-university, two-class research project in which asynchronous discussion board entries were analyzed for substance. By using oral discourse analysis techniques, the postings of two distinct structures of discussion board entries were analyzed. A baseline of typical student interactions was established by using an Open-ended discussion board assignment. The requirements were then changed and an Experimental discussion board format was introduced-students were placed into smaller groups and expected to enact a 3R pattern of Respond, React, and Reply. The ways in which students made their thinking visible were coded and tabulated. Findings suggest that a Connected Stance, identified by a high level of participation coupled with a high level of engagement, was an optimal online discourse pattern.
\end{abstract}

\section{INTRODUCTION}

Researchers have explored the structure of online interactions [1, 2]. Few, however, have examined the content of students' responses [3, 4]. As researchers and instructors, is it enough to know that students are using a certain number of words when they post responses to online asynchronous discussion boards? Or, should online instructors focus more on the substance of students' posts? Similarly, if both are evident to some degree in rich discussions, how can both be simultaneously considered, measured, or captured? This manuscript reports on the close analysis of student postings to determine the substance and structure that encouraged students' responses. This research project was informed by social interactionism [5, 6], computer-mediated communication [7, 8], and discourse analysis [9, 10].

The purpose of this article is to describe the substance and amount of optimum asynchronous online interactions. In order to accomplish this, online postings were analyzed to reveal the substance of students' remarks, as well as the number of words used in students' posts. Although earlier studies in online teaching have identified ways students reach mastery of content [11-13], little analytic attention has been paid to the substance of students' remarks on discussion boards. This gap in knowledge is addressed by studying the moves or various reasons why participants join an online conversation. This research study does not seek to articulate a generalization that explains all online interactions. On the contrary, online interactions are complex and defy simplistic definitions. Therefore, to study these phenomena, the following questions guided the present study:

1. How does structure influence the number of moves and the length of postings that students offer?

2. How do moves found in online discussions reveal an optimum discourse? 


\section{A. The Nature of Social Interactions}

Interaction, as defined by Simpson and Galbo [14], is the "behavior in which individuals and groups act upon one another . . . a continually emerging process, as communication in its most inclusive sense" (p. 38). According to Vygotsky [6], social interactions are key components of any learning event, and such interactions are necessary for learning to occur. Most face-to-face interactions in a classroom setting are characterized by an initiate, respond, evaluate pattern - or IRE [10]. In this pattern, a teacher initiates discussion with a question, students respond to the question, and the teacher evaluates students' responses. The IRE pattern is comprised of three distinct moves: teacher initiation, student response, and teacher evaluation. As a whole, the moves found in the IRE pattern make up a particular stance. Broadening this idea, each student assumes a particular stance in general toward a concept or activity which results in a particular move.

Even though the IRE pattern is prevalent, it is not the optimum interaction pattern for teachers or students. It does not create a "community of inquiry" [15] that is essential to the development of higher level, critical thinking skills [16]. Warnock, Bingham, Driscoll, Fromal, and Rouse [17], found that first posters to online discussion boards received better grades than the class final average. Warnock et al. also correlated course performance with average post length; the researchers found earlier discussion posts to be longer in length on average than latter posts. Teachers and learners who assumed a Connected Stance, or one in which participants used language to engage with the content and participate in the co-creation of knowledge with their peers and teacher [18], felt higher satisfaction in their coursework, and received higher grades.

A Connected Stance, by definition, breaks the IRE pattern. Discussions are built one interaction at a time. Comments, statements, questions, and assertions are made which cue additional comments, statements, questions, and assertions. In a Connected Stance, layer upon layer, students build their understanding, clarify their thinking, and, hopefully, move into new uncharted waters.

Unlike the IRE pattern which limits student interaction via a limited number of possible moves, Connected Stance patterns allow students to employ a variety of moves, essentially doing more with their language. Students who assume a Connected Stance typically use higher levels of thinking, which encourages a deeper engagement with content. This higher level of thinking also supports a more thorough understanding of the topic. In order to understand the language-in-use in asynchronous online courses, a study of discourse patterns is essential. Identifying major discourse patterns, such as a Connected Stance or an IRE pattern, provides valuable information to instructors.

The IRE pattern limits interactions (identified by moves) that participants would make. Because discourse patterns shape the communication and thinking of the classroom [9], it is essential that rich discussions which lead to deeper thinking be encouraged [19].

Interactions are also a major construct in understanding online learning [20-22]; in online environments, interactions are mediated by the computer, adding to the complexity of online communication [23] In many online classes, IRE patterns are also used [24] in which the instructor posits a question, students respond, and the teacher (or other students) evaluate the response.

To move away from an IRE pattern and to encourage a more Connected Stance, interactions need to be an intentional instructional design component within the online course [25-29]. Faculty need "a wide range of pedagogical instruction that fosters cohesion and student engagement” [30, p. 16]. Students need to have ample opportunity to respond to each other on discussion boards and within group activities [31] Although Simonson, Smaldino, Albright, and Zvacek [32] suggest more interaction is not necessarily better, there is evidence that a positive correlation exists between the number of interactions and higher post-test scores [17, 33].

Additionally, increasing the opportunity for students to participate can enhance social presence-i.e., the degree to which the user feels connected in a computer-mediated interaction [34-36]. Researchers report that social presence contributes to student motivation and enhances online interaction. In fact, Rourke, Anderson, Garrison, and Archer [37] report that a strong sense of social presence can influence a 
student's stance. In other words, if students are enacting an IRE pattern and is convinced that their instructor is also, they will respond using a narrow number of possible moves Wang, Newlin, and Tucker [38] report a strong correlation between several discourse types and class performance as indicated by final grades. The study supports the notion that "the form and frequency of cyber-students' communicative activity provides critical information regarding their involvement and performance in Internet-based classes” (p. 226). Even though Wang, Newlin, and Tucker focused on synchronous discussion boards, which more closely mimic real-time discussions in face-to-face classrooms, their analysis can inform the way researchers analyze asynchronous computer-mediated interactions, which is the topic of this present study.

\section{B. Computer-Mediated Communication}

The use of computer technology to offer course work, in part or whole, is not only becoming more popular with students but is also becoming a necessary offering if universities hope to keep a competitive edge in the $21^{\text {st }}$ century. It is no longer a new way to augment course work-it is an expected learning component for the e-generation of digital natives. Online courses make it possible for students to make choices such as when to log in, what to access, and to whom to respond. Within an asynchronous environment, students have more time to think about their answers and search for additional information that supports their comments [39, 40]. Interacting in an online environment allows learners to reread and reflect on the contributions of others in the group, and to craft answers that are thoughtful and thorough. Because interaction is an important component of any learning event [6, 41], it has been identified as one of the major constructs in online learning [20-22].

Studies have emphasized the importance of active participation among students in promoting the effectiveness of online learning [42-46] and improved academic performance [25, 17]. Additionally, students believe they learned more when expected to contribute to group discussion [33]. Moore [43] reports that, "for effective interaction, students and faculty benefit from clear expectations about communicating; clear expectations help manage the volume and quality of interaction” (p. 97). Beckett, Amaro-Jimenez, and Beckett [47] similarly argue that non-English speaking students in particular need explicit instructions and guidance in an online environment.

It is therefore important to design a cyber-environment that encourages a high level of student communication or interactions that go beyond the simple sharing of ideas [48, 49]. This can be accomplished by "establishing norms that invite students to participate, and that establish routines and conventions to support student engagement" [3; p. 177]. Because all communication is text-based in online courses, the substance of interactions can be closely examined by instructors and researchers via oral discourse analysis techniques.

\section{Discourse Analysis}

One way of examining student moves is through the lens of a dialogic chain [5]. This dialogic chain makes visible the interaction that occurs between participants and often sets the course for new learning. Rex, et al. [50], found that discourse participation relates to access, meaning students' notions of new learning opportunities influence face-to-face interactions. According to Bakhtin [5], all utterances are in answer to, anticipation of, or a continuation of, other utterances. These utterances can range from a simple sigh, to a complete novel. Discussion boards, which are used as the vehicle for online interactions [7, 51], can be used to analyze moves and chains of utterances of participants, which may take place over the course of a few days or an entire semester. Words students post can be coded for possible moves, or reasons why participants joined in the conversation. Discussion boards offer the best way to determine the kinds of stances - or reasons for contributing to the conversation - that learners are assuming. If postings are in a traditional IRE pattern, the codes of "initiating a topic" and "evaluating a response" are typical moves for teachers. Students, on the other hand, are generally limited to the move of "responding to teachers' questions."

Discourse analysis can also reveal when discussions are moving away from the IRE pattern to reveal 
social presence $[37,35,36]$ among participants and, perhaps, a more optimal Connected Stance interaction [28]. In contrast to the IRE pattern, students enacting a Connected Stance display a variety of moves. For example, the following moves were found in online discussion posts [28]:

- Introducing a new topic

- Connecting to other readings

- Connecting to their own classroom

- Connecting to their own thinking (reflecting)

- Challenging a peer

- Initiating their own topics

- Questioning/Wondering

These moves are much more powerful than those following the typical IRE patterns, and yield richer conversations which, in turn, increase student understanding. The above moves represent higher levels of engagement with the content. In mathematics, Imm and Stylianou [52] report on the important relationship between cognitively demanding tasks and mathematical talk, and the power of discourse as a "thinking device" as opposed to merely a conduit of knowledge. In other words, one link in a chain of utterance [5] can prompt thinking deeply about other links, establishing rich patterns of interactions. Thus, to closely examine the level of engagement in online learning, it is critical to understand the patterns of discourse in the online dialogic chain.

\section{METHODOLOGY}

\section{A. Participants and Context}

The 32 participants for this study were practicing teachers enrolled in Master of Education in Reading programs at two universities. One of the two universities was located in a rural setting with 15,000 students. Dr. Adams (his and all other names were replaced by pseudonyms) was a Professor and had been teaching at the college level for 35 years. The targeted course from this university was an educational theory course which included textbook and outside readings, research synthesis, group activities, online discussions, and in-school presentations. The second university was located in an urban setting and had over 50,000 students. Dr. Burns was an Assistant Professor, with 11 years of experience at the college level. The targeted course from this university focused on content area literacy and included textbook and outside readings, research synthesis, group activities, online discussions, and digital storytelling. Both courses were within the first year of the graduate program, and both were conducted fully online. Both instructors expected participants to apply theories to classroom practices.

\section{B. Procedures.}

This study uses a participant observation approach [53] that is naturalistic [54] and interpretive [55]. In these research paradigms, investigators systematically analyze bounded systems [56] in order to understand the specifics of naturally occurring situations. Asynchronous discussion boards offer such a system, with clear-cut boundaries.

Asynchronous discussion boards from two Master's courses at two separate universities were examined to understand the dialogic chains [5] in action. By using discourse analysis techniques, the textual moves from two different discussion board types (Open-ended and Experimental) were coded. To analyze the moves used by students, an idea or theme (unit of meaning) of a message was identified and used as the unit of analysis. These units could be a word, a phrase, an emoticon, a sentence, a paragraph, or an entire posting. These units of meaning were classified as moves (Table 1).

Some students' postings fit into two or more categories of moves. These were coded as many times as they were represented. In other words, this statement was coded as follows: "I am getting the impression (Code \#7) that children—or at least the majority of children—are not being read to anymore. (Code \#2/3) 
So, how can I convince parents to read to their children?” (Code \#10)

\begin{tabular}{|c|c|}
\hline Moves & Example Statements \\
\hline 1. Introducing a new topic & $\begin{array}{l}\text { I know that we are talking about reading in science, but I } \\
\text { find myself trying to motivate my students to read in order } \\
\text { to be successful in math. }\end{array}$ \\
\hline $\begin{array}{l}\text { 2. Sharing opinion/ 3. Sharing } \\
\text { beliefs }\end{array}$ & $\begin{array}{l}\text { The teacher must be able to relate to the students and to } \\
\text { know what their background is. }\end{array}$ \\
\hline $\begin{array}{l}4 . \text { Connecting to other } \\
\text { readings }\end{array}$ & $\begin{array}{l}\text { I have read much in another class on how SAT or FCAT is } \\
\text { biased toward a white American perspective. }\end{array}$ \\
\hline $\begin{array}{l}\text { 5. Connecting to their own } \\
\text { experiences }\end{array}$ & $\begin{array}{l}\text { I can vividly remember lacking this kind of direction in the } \\
\text { majority of my own middle and high school classes. }\end{array}$ \\
\hline $\begin{array}{l}\text { 6. Connecting to their own } \\
\text { classrooms }\end{array}$ & $\begin{array}{l}\text { For example, I have a seventh grade Language Arts class } \\
\text { with two students reading at level four, ten at level three, } \\
\text { four at level two, and five at level. Although it takes extra } \\
\text { planning and time, I have to find activities that will both } \\
\text { challenge my level threes and fours while at the same time } \\
\text { reach my level ones and twos. }\end{array}$ \\
\hline $\begin{array}{l}\text { 7. Connecting to their own } \\
\text { thinking } \\
\text { (reflecting) }\end{array}$ & $\begin{array}{l}\text { I am looking forward to creating more of a participant } \\
\text { atmosphere where literacy is concerned and not only guiding } \\
\text { the students toward information and higher-thinking, but } \\
\text { also having them guide each other. }\end{array}$ \\
\hline 8. Building rapport & Wow! Thanks for being first and for such a great response! \\
\hline $\begin{array}{l}\text { 9. Suggesting a new } \\
\text { organizational theme }\end{array}$ & $\begin{array}{l}\text { One teacher even does a mathematics journal so that } \\
\text { students can write out the processes that they use to solve } \\
\text { problems in words. This way, the requirements of the state } \\
\text { are met and she doesn't have to do any "mushy" (her words) } \\
\text { writing! }\end{array}$ \\
\hline $\begin{array}{l}\text { 10. Revealing their own } \\
\text { struggles }\end{array}$ & $\begin{array}{l}\text { I don't know if I'm really doing these children any good by } \\
\text { requiring this assignment. }\end{array}$ \\
\hline $\begin{array}{l}\text { 11. Responding to another } \\
\text { peer's question }\end{array}$ & $\begin{array}{l}\text { I think both stances have a place in the classroom, but the } \\
\text { key is to know when one is more appropriate to use. }\end{array}$ \\
\hline 12. Giving information & $\begin{array}{l}\text { Getting students actively involved in discussion helps them } \\
\text { to better understand and retain the material. This method } \\
\text { allows the student to use and expand their LERs. }\end{array}$ \\
\hline 13. Giving advice & $\begin{array}{l}\text { Once you start teaching, the material will become second } \\
\text { nature to you and you will be fine. }\end{array}$ \\
\hline $\begin{array}{l}\text { 14. Connecting to a previous } \\
\text { thought }\end{array}$ & $\begin{array}{l}\text { I can definitely see what you're talking about. If a teacher } \\
\text { can create a true aesthetic stance for students toward } \\
\text { academia, that is a true accomplishment. }\end{array}$ \\
\hline $\begin{array}{l}15 . \quad \text { Questioning } \\
\text { wondering) }\end{array}$ & $\begin{array}{l}\text { If a student cannot find something about which to say, "I've } \\
\text { always wondered about that!" or "So that's what that is!" or } \\
\text { "I'm not so sure that is true," then has the teacher really } \\
\text { taught that student the deepest meaning of science? }\end{array}$ \\
\hline
\end{tabular}




\begin{tabular}{|l|l|}
\hline 16. Giving an example & $\begin{array}{l}\text { Simply having students passively read and regurgitate } \\
\text { answers does not enrich the learning experience. Hands-on } \\
\text { experiments, communication with peers through class } \\
\text { discussion, field trips, and other real-life experiences build } \\
\text { upon students' already existing LERs. }\end{array}$ \\
\hline $\begin{array}{l}\text { 17. Sharing "Grand idea" } \\
\text { (sweeping } \\
\text { generalization) }\end{array}$ & It's important that all teachers create a risk free environment. \\
\hline $\begin{array}{l}\text { 18. Challenging a peer } \\
\text { content }\end{array}$ & $\begin{array}{l}\text { While I like your idea of a common ground, I'm not quite } \\
\text { sure if that is always attainable. Students come from so } \\
\text { many different backgrounds and different understandings of } \\
\text { topics that finding a common ground might be difficult. }\end{array}$ \\
\hline $\begin{array}{l}\text { 19. Using humor } \\
\text { connecting to course }\end{array}$ & $\begin{array}{l}\text { It is the two-and-fro interplay of the literacy definition I find } \\
\text { most valuable. }\end{array}$ \\
\hline & $\begin{array}{l}\text { I say to myself, "I know these ideas are how things should } \\
\text { be." But I find myself saying, "*sigh... This is harder than I } \\
\text { thought it would be!" I am having a hard time separating my } \\
\text { feelings for certain of my "knucklehead" students. }\end{array}$ \\
\hline
\end{tabular}

Table 1. Discourse Analysis Moves

In addition to the two authors of this manuscript, two graduate students were trained to analyze student postings on discussion boards in order to test researcher fidelity. An inter-rater reliability of $74 \%$ was attained between all four coders through a reconciliation process which included questioning, challenging, and a thorough discussion of coding procedures; a high level of understanding was achieved by all coders.

Two discussion formats were used. The first, an Open-ended discussion board, expected students to interact but gave few specific directions. The second, an Experimental discussion board, was preceded by descriptive instructions which also carefully explained the timing and substance of effective postings. In both discussion formats, students were given a detailed rubric by which their discussions were evaluated.

General directions for the Open-ended discussion board were given: respond to the teacher-generated discussion question by Tuesday, discuss with classmates throughout the week, and wrap up the discussion by Saturday. Students were referred to a discussion rubric (Appendix A) to help guide their postings. Examples of exemplary discussion postings were also provided to students (Appendix B). Both courses used an Open-ended discussion board format for the first half of the semester. For postings within this format, it was found most of the discussions to have stopped after each participant commented on the initial discussion thread posting of a peer. In addition, the majority of comments to peers' postings had little substance. On these Open-ended boards, few comments helped with the co-creation of knowledge [57], nor added to the understanding of course content. For example, typical responses of students included phrases like:

- (after a 153 word initial posting) “Good job!”

- (after a 75 word initial posting) "Keep up the good work"

- (after a 210 word initial posting) "I like what you said about the writing process."

- (after a 64 word initial posting) "I agree with everything you said.”

In order to determine whether structure affected the types of moves students enacted, as well as increase the number of responses and improve the overall quality of the discussion, instructors changed the discussion board requirement. The format for posting was altered according to the results of a previous pilot study [28]. In this previous research project, it was found students enacted a minimal amount of moves in an Open-ended discussion board prompt. One recommendation from the study, in order to extend and lengthen conversations, was the need for students to be assigned to react and reply to their 
peers within a group setting.

Approximately halfway through the courses in the present study, a $3 \mathrm{R}$ format was created for the Experimental discussion boards: Respond, React, Reply. The new weekly directions were to Respond to a discussion question by Tuesday, React to group peers by Thursday, and Reply to those who reacted by Saturday. Not only were students reminded of the discussion rubric, students were given examples for the expected and unacceptable levels of the React component of the 3R pattern. (See Appendix B for examples.) Both courses used Open-ended discussion boards for the first half of the course and Experimental discussion boards for the second half of the course.

All postings of 32 students were formatted for analysis from one Open-ended and one Experimental discussion board. The postings were coded according to the moves students made. The saturation point, or the point at which no further moves were visible, was reached after 19 moves, which are shown in Table 1. (Moves 2 and 3 were later combined to bring the total count of moves to 19 instead of 20.) In other words, researchers found that 19 moves explained all of the moves that students took during the discussion posts.

Student responses within the Open-ended and Experimental discussion boards were compared in terms of word count and variety of moves. Word count signaled levels of participation and variety of moves signaled levels of engagement.

Since this study focused on only 32 participants, quantitative methods were not used to try to attain significance. Instead discussion board entries served as the data source for this study. Over 200 pages were transcribed, formatting the data into two three-inch columns and coding the data according to the list of 19 moves.

\section{RESULTS}

In Dr. Adams' class, the number of words on the discussion boards ranged from 398 to 1028, and the variety of moves ranged from 7 to 17. In Dr. Burns' class, the number of words ranged from 92 to 712 and the variety of moves ranged from 2 to 15 . Grades in Dr. Adams' class ranged from 80-96\% and Dr. Burns' class grades ranged from $70-100 \%$. (See Table 2.)

\begin{tabular}{|l|l|l|}
\hline & Dr. Adams & Dr. Burns \\
\hline Range of Grades & $80-96 \%$ & $70-100 \%$ \\
\hline Range of number of words & $398-1028$ & $92-712$ \\
\hline Range of moves & $7-17$ & $2-15$ \\
\hline
\end{tabular}

Table 2. Grades, Number of words, and Range of moves across both classes

The differences in grades, number of words, and number of moves between classes can be attributed to several factors:

1. Number of questions: Dr. Adams directed students to respond to two questions within the targeted open posting while Dr. Burns directed students to respond to only one question. Thus, Dr. Adams' students needed more words to answer the higher number of questions, as well as more moves to craft their responses.

2. Interactions with students: Dr. Adams had a total of 10 students, while Dr. Burns had 22 students. Thus, Dr. Adams was able to give more individual feedback which may have prompted students to respond and react more in-depth.

Instead of an exhaustive analysis of all 32 students, this study focuses on six representative students according to high, middle, and low grades in each class. Table 3 verifies that this selection reflected typical high, middle, and low performers in each class. 


\begin{tabular}{|l|l|l|l|}
\hline $\begin{array}{l}\text { Class Performance } \\
\text { Level }\end{array}$ & $\begin{array}{l}\text { Years of } \\
\text { Teaching, at the } \\
\text { time of study }\end{array}$ & $\begin{array}{l}\text { Grade level } \\
\text { taught during } \\
\text { focus semester }\end{array}$ & Gender \\
\hline Dr. Adams' & & & \\
\hline Low & 2 & 2 and 3 & Female \\
\hline Middle & 3 & 1 st & Female \\
\hline High & 8 & 4 & Female \\
\hline Dr. Burns' & & & \\
\hline Low & 4 & 6 & Female \\
\hline Middle & 5 & 9 & Female \\
\hline High & 7 & 10 & Male \\
\hline
\end{tabular}

Table 3. Demographic Information about Six Focus Participants

Even with the differences in total word count and the variety of moves between classes, the six students chosen represent the overall range of responses. The number of words and the variety of moves made were tabulated for both the Open-ended and Experimental discussion boards. Table 4 displays these results.

\begin{tabular}{|c|c|c|c|c|c|c|}
\hline & $\begin{array}{c}\text { Dr. } \\
\text { Adams' } \\
\text { class } \\
\end{array}$ & & & $\begin{array}{c}\text { Dr. Burns' } \\
\text { class }\end{array}$ & & \\
\hline & $\begin{array}{l}\text { Lower } \\
\text { performer }\end{array}$ & $\begin{array}{l}\text { Middle } \\
\text { perform } \\
\text { er }\end{array}$ & $\begin{array}{l}\text { Higher } \\
\text { performer }\end{array}$ & $\begin{array}{l}\text { Lower } \\
\text { performer }\end{array}$ & $\begin{array}{l}\text { Middle } \\
\text { performer }\end{array}$ & $\begin{array}{l}\text { Higher } \\
\text { performer }\end{array}$ \\
\hline Final Grades & $80 \%$ & $90 \%$ & $96 \%$ & $88 \%$ & $95 \%$ & $97 \%$ \\
\hline $\begin{array}{l}\text { Number of } \\
\text { Words Open- } \\
\text { ended }\end{array}$ & 402 & 578 & 638 & 96 & 258 & 612 \\
\hline $\begin{array}{l}\text { Number of } \\
\text { words } \\
\text { Experimental }\end{array}$ & 630 & 945 & 1028 & 283 & 485 & 583 \\
\hline $\begin{array}{l}\text { Variety of } \\
\text { Moves Open- } \\
\text { ended }\end{array}$ & 9 & 10 & 13 & 6 & 8 & 9 \\
\hline $\begin{array}{l}\text { Variety of } \\
\text { moves } \\
\text { Experimental }\end{array}$ & 11 & 14 & 17 & 7 & 10 & 11 \\
\hline
\end{tabular}

Table 4. Final Comparison of Open-ended and Experimental discussion boards in number of words and moves between six focus participants 


\section{DISCUSSION}

\section{A. Research Question \#1: How does structure influence the number of moves and the length of postings that students offer?}

When the six focus students responded to prompts from the Open-ended discussion boards, it is evident that they indeed responded to posed questions and reacted to each other's responses. It is interesting to note, however, that none of the six participants (nor any of the students in either of the two classes) continued the Open-ended discussion by replying to the reactions posted by their peers. The discussions in each case stopped after the second posting (the reaction); no interactions carried the discussions forward. In contrast, when the structure of the assignments changed from an Open-ended response to a more specific 3R pattern of respond, react, and reply the results were much different. On the Experimental discussion board students responded to the question, reacted to their colleagues, and continued the conversation by replying to those reactions. In some cases, interactions continued beyond the third R (reply).

More importantly, the increase in the length of postings on the Experimental discussion boards resulted in students using more varied moves. The total number of moves increased from the Open-ended to the Experimental discussion boards. Layer upon layer, more interactions occurred when students were participating in the Experimental discussion board. Thus, the structure of the Experimental discussion board built in opportunities for interactions, which increased the likelihood of social presence resulting in a Connected Stance.

\section{B. Research Question \#2: How do moves found in online discussions reveal an optimal discourse?}

For purposes of this study, a Connected Stance is identified as the nexus of high engagement and high levels of participation [18]. Participation was measured by measures of word count, and engagement was measured by the variety of student moves. Displayed in graphic format (variety of moves and number of words in both Open-ended and Experimental discussion boards) it is clear that there was movement to the top right quadrant for each of the six focused students. See Figure 1 for representations of the high, middle, and lower performing students in both Dr. Adams' and Dr. Burns' classes. 


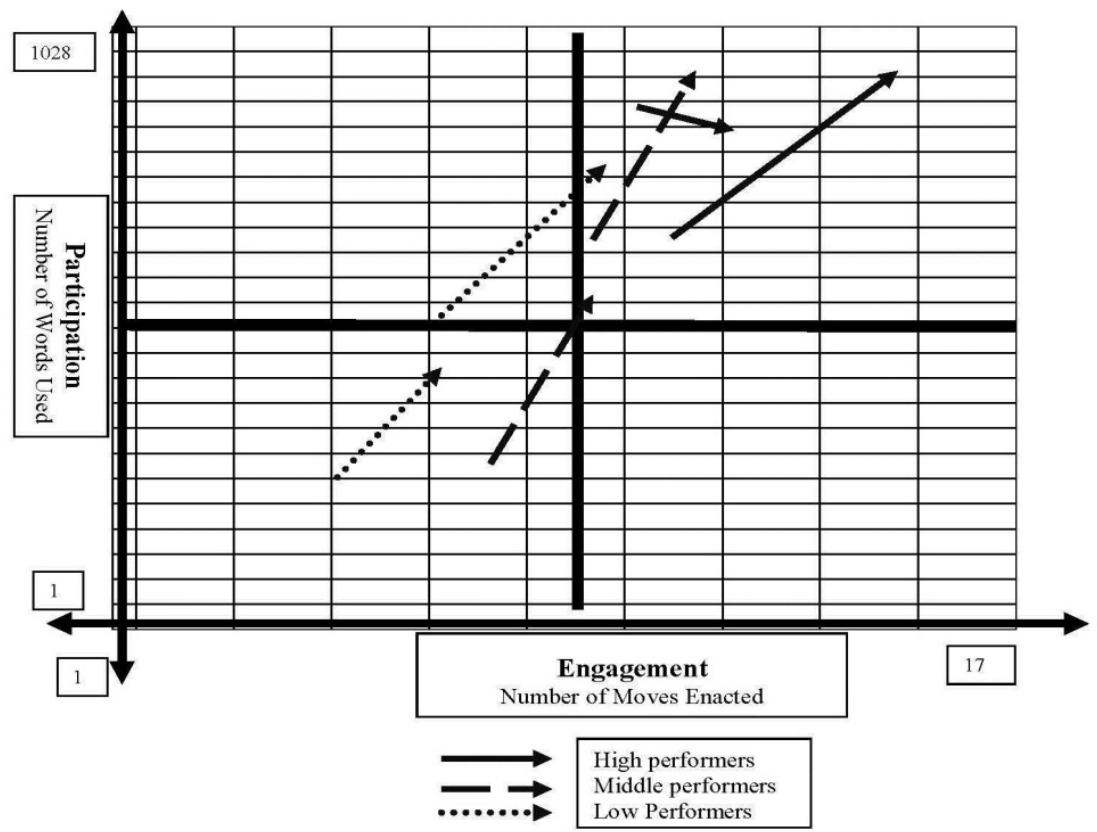

Figure 1. Representations of 6 high, middle, and low performing students.

Interestingly, all students moved toward the upper right quadrant. This represented the highest number of moves and the highest level of participation. This quadrant most closely represented a Connected Stance. Students showed an increase in the number of words, as well as the number of moves when the discussion board was adjusted from Open-ended to Experimental. Thus the quadrants are labeled as follows:

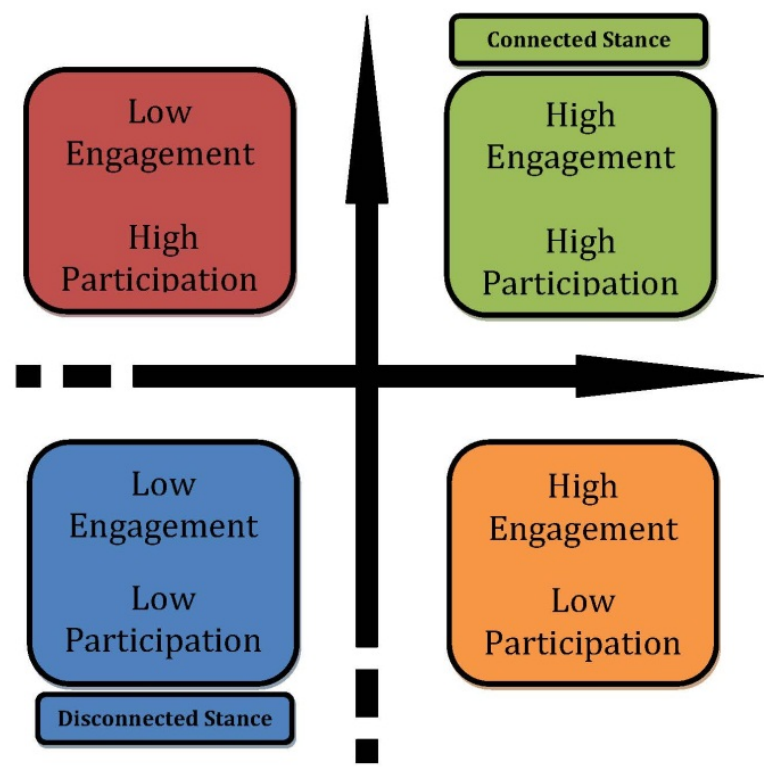

Figure 2. Graphical representation of the Connected Stance in Quadrant 
Regardless of the structure of the discussion boards, both of the lower performers started in the lower left quadrant. Because these students were not as engaged as their colleagues, they were disconnected from the conversations. This lower left-hand quadrant, therefore, is labeled as "Disconnected Stance." However, comparing their initial and final discussion activities, even the lower performing students moved toward the upper right quadrant, labeled as Connected Stance. They increased in participation and engagement and thus moved toward a more optimal discourse pattern.

Both middle performers moved from the lower left quadrant to the upper right quadrant. Although they began by enacting Disconnected Stances within the Open-ended discussion boards, they enacted Connected Stances within the Experimental discussion boards.

On the Open-ended discussion board, the highest performer in Dr. Adams' class had high engagement but lower participation. However, with the added structure of the Experimental discussion board, her participation increased and she transitioned to a Connected Stance. The highest performing student in Dr. Burns' class began and sustained a Connected Stance throughout the course. His level of engagement increased even though his number of words decreased slightly.

Five out of the six focus students moved toward the upper right quadrant that represented high participation and high engagement. The sixth student persisted in the upper right quadrant.

\section{IMPLICATIONS}

The results of this study indicate it is possible for online instructors to increase student engagement by making expectations explicit for rich interactions. The structure of the 3R format (Respond, React, Reply), the use of detailed rubrics, and the use of clear examples can increase the variety of moves and the number of times students are required to post. All of these factors encourage a more Connected Stance.

Thus, it is important that instructors have a clear understanding of their expectations for rich discussions. These expectations need to be translated into a detailed rubric so that expectations can be made explicit to students. Rubrics should be accompanied by examples that illustrate both acceptable and unacceptable postings. In addition, students need to know the rationale behind rich online interactions. For example, enacting a Connected Stance supports learning of course content. These specific course expectations should be communicated early in the course.

Instructors can use a 3R structure (Respond, React, Reply) to encourage a Connected Stance. Purposefully increasing the number of times students are required to interact and expecting a variety of moves will increase the involvement and engagement of students with each other and lead to richer discussions.

\section{LIMITATIONS}

Limitations of this study include the instructors' assessments of student performance levels. Inherent in this kind of judgment is a subjective determination of students. The instructor should use student-created work to determine whether students are higher, middle, or lower performers. Implications for studying a Connected Stance will need to ameliorate researchers' perspectives of student levels with objective data. Another consideration is the vast amount of time required to consider students' moves, in order to determine their stance

\section{FUTURE RESEARCH}

Future research could include a closer examination of the relationship between the moves enacted and Bloom's Taxonomy [58]. Do some moves indicate a higher level of thinking? If higher levels of Bloom's taxonomy correlate to student success, could online discussions be coded for indications of higher levels of Bloom's taxonomy? 
Another area of study could involve the use of the 19 coded moves that were identified. Should instructors describe moves explicitly and then expect students to use a variety of them? How much feedback should be given to students concerning the kinds of moves they can enact?

Perhaps an even broader study would look at participants themselves and what they bring to the learning environment. Are there differences in personality types and the kinds of postings students make? Do cultural differences influence the types of moves students are willing to enact? Does the number of years of teaching experience have any correlation with the teachers' depth of discussion?

\section{CONCLUSION}

As United States colleges and universities move toward more online offerings, more research needs to occur in computer-mediated communication (CMC). Since interaction between participants is a major construct of CMC, more fine-tuned analysis of these interactions is needed. Participation alone is not an adequate indication of a successful interaction. Rather, analysis of the substance of postings is needed to carefully design an environment that moves beyond the simple sharing of ideas.

In this study, adjusting the structure of online discussion boards influenced participation and engagement levels. Explicit, thoughtful, and clear directions were necessary to make rich discussion transparent. Restructured discussion boards were accompanied by detailed rubrics and clear examples so that students knew how to move toward a more Connected Stance. When this occurred, students went well beyond the Initiate-Respond-Evaluate (IRE) pattern [10]. Instead they challenged their peers, revealed personal struggles, connected to other texts, asked questions, wondered about concepts, etc. As one of the six focus participants said about the Experimental discussion boards, "They promoted more interaction since there was higher expectation and structure. Classmates responded at a more thoughtful level." This study reinforces the belief that moving students toward a more Connected Stance provides deeper levels of interaction and understanding of course content.

\section{REFERENCES}

1. Jones, Q., Ravid, G., and Rafaeli, S. Information Overload and the Message Dynamics of Online Interaction Spaces: A Theoretical Model and Empirical Exploration. Information Systems Research 15(2): 194-210 (2004). doi:10.1287/isre.1040.0023.

2. Savenye, W.C. Improving Online Courses: What is Interaction and Why Use It? Distance Learning 2(6): 22-29 (2005).

3. McCrory, R., Putnam, R., and Jansen, A. Interaction in Online Courses for Teacher Education: Subject Matter and Pedagogy. Journal of Technology and Teacher Education 16: 155-180 (2008).

4. Wegmann, S., and McCauley, J. Investigating Asynchronous Online Communication: A Connected Stance Revealed. Proceedings for Sloan Consortium Annual Conference, Orlando, FL., November 5, 2010.

5. Bakhtin, M., The Problem of Speech Genres. In: Speech Genres and Other Late Essays, Bakhtin, M. (Ed.), 60-102, Austin: University of Texas Press, 1986.

6. Vygotsky, L.S., Mind in Society, Cambridge: Harvard University Press, 1978.

7. Burnette, G., and Buerkle, H. Information Exchange in Virtual Communities: A Comparative Study. Journal of Computer Mediated Communication 9(2) (2004). http://www.ascusc.org/jcmc/vol9/issue2/burnett.html.

8. Gunawardena, C.N., Lowe, C.A., and Anderson, T. Transcript Analysis of Computer-Mediated Conferences as a Tool for Testing Constructivist and Social-Constructivist Learning Theories. In: Distance Learning '98. Proceedings of the Annual Conference on Distance Teaching and Learning 139-145 (1998). 
http://www.eric.ed.gov/contentdelivery/servlet/ERICServlet?accno=ED422854.

9. Cazden, C., Classroom discourse, Portsmouth, NH: Heinemann, 1988.

10. Mehan, H., Learning Lessons, Cambridge: Harvard University Press, 1979.

11. Moore, M.G., and Kearsley, G. Distance Education: A Systems View, Belmont: Thomson Wadsworth, 2005.

12. Richardson, J.C., and Newby, T. The Role of Students' Cognitive Engagement in Online Learning. The American Journal of Distance Education 20(1): 23-37 (2006).

13. Salmon, G., Etivities: The Key to Active Online Learning, Sterling: Kogan Page Limited, 2003.

14. Simpson, R.J., and Galbo, J.J. Interaction and Learning: Theorizing on the Art of Teaching. Interchange 17(4): 37-51 (1986).

15. Akyol, Z. Arbaugh, J.B., Cleveland-Innes, M., Garrison, D.R., Ice, P., Richardson, J.C., and Swan, K. A Response to the Review of the Community of Inquiry Framework. Journal Of Distance Education 23(2): 123-136 (2009).

16. Lipman, M., Thinking in Education, NY: Cambridge University Press, 1991.

17. Warnock, S., Bingham, K., Driscoll, D., Fromal, J., and Rouse, N. Early participation in asynchronous writing environments and course success. Journal of Asynchronous Learning Networks 16(1): (2012).

18. Author and Author, Can you hear us now? Stances toward interaction and rapport. In: Y. Inoue (Ed.), Online Education for Lifelong Learning, Hershey, PA: Information Science Publishing, 2007.

19. Newman, D.R., Webb, B., and Cochrane, C. A Content Analysis Method to Measure Critical Thinking and Computer Supported Group Learning. Interpersonal Computing and Technology: An Electronic Journal for the 21st Century 3(2): 56-77 (1995).

20. Li, Q., and Akins, M. Sixteen Myths About Online Teaching and Learning in Higher Education: Don’t Believe Everything You Hear. TechTrends 49(4): 51-60 (2005).

21. Shovein, J., Huston, C., Fox, S., and Damazo, B. Challenging Traditional Teaching and Learning Paradigms: Online Learning and Emancipatory Teaching. Nursing Education Perspectives 26(6): 340-343 (2005).

22. Vrasidas, C. A Working Typology of Intentions Driving Face-to-Face and Online Interactions in a Graduate Teacher Education Course. Journal of Technology and Teacher Education 10(2): 273-297 (2002).

23. Mondada, L. Participants' Online Analysis and Multimodal Practices: Projecting the End of the Turn and the Closing of the Sequence. Discourse Studies 8(1): 117-129 (2006).

24. Wegmann, S. Engaging the Mind through the Fingers: An Analysis of Online Interaction and Stance, In: Falk-Ross, S., Foote, R., Linder, P., Sampson, C., and Szabo, S. (Eds.), 2006 CRA Yearbook Volume 28, 2007.

25. Althaus, S.L. Computer-mediated Communication in the University Classroom: An Experiment with Online Discussions. Communication Education 46: 158-174 (1997).

26. King, J.C., and Doerfert, D.L., Interaction in the Distance Education Setting, 1996. http://www.ssu.missouri.edu/ssu/AgEd/NAERM/s-e-4.htm.

27. Smith, R. Working with Difference in Online Collaborative Groups. Adult Education Quarterly 55(3): 182-199 (2005).

28. Wegmann, S. “Cross Talk” Online: A Case Study of One Successful Student’s Online Interactions. In: B. Olaniran (Ed.) Cases on Successful E-Learning Practices in the Developed and Developing World: Methods for the Global Information Economy, Hershey, PA: IGI, 2009.

29. Zhang, W., Perris, K., and Yeung, L. Online Tutorial Support in Open and Distance Learning: Students’ Perceptions. British Journal of Educational Technology 36(5): 789-804 (2005).

30. Lynch, D., Kearsley, G., and Thompson, K. Faculty use of asynchronous discussions in online learning. International Journal of Instructional Technology \& Distance Learning 8(2): (2011). http://www.itdl.org/Journal/Feb_11/article02.htm.

31. Ruan, J., and Beach, S. Using Online Peer Dialogue Journaling to Promote Reflection in Elementary Preservice Teachers. Action in Teacher Education 27(3): $64-75$ (2005). 
32. Simonson, M., Smaldino, S., Albright, M., and Zvacek, S., Teaching and Learning at a Distance: Foundations of Distance Education, Upper Saddle River: Prentice Hall, 2000.

33. Brewer, S. and Klein, J., Small Group Learning in an Online Asynchronous Environment. Chicago, IL: Association for Educational Communications and Technology, 2004. http://www.eric.ed.gov/contentdelivery/servlet/ERICServlet?accno=ED484997.

34. Moore, M.G. Distance Education Theory. The American Journal of Distance Education 5(3): 1-6 (1991).

35. Short, J., Williams, E., and Christie, C., The Social Psychology of Telecommunications, London: Jon Wiley and Sons, 1976.

36. Stein, D.S., Wanstreet, C.E., Calvin, J., Overtoom, C., and Wheaton, J.E. Bridging the Transactional Distance Gap in Online Learning Environments. The American Journal of Distance Education 19(2): 105 (2005).

37. Rourke, L., Anderson, T., Garrison, R., and Archer, W. Assessing Social Presence in Asynchronous Text-based Computer Conferencing. Journal of Distance Education 16 (2): 1-14 (2001).

38. Wang, A., Newlin, M., and Tucker, T. A Discourse Analysis of Online Classroom Chats: Predictors of Cyber-Student Performance. Teaching of Psychology 28(3): 222-226 (2001).

39. Du, J., and Xu, J. The Quality of Online Discussion Reported by Graduate Students. Quarterly Review of Distance Education 11(1): 13-24 (2010).

40. Pena-Shaff, J.B., and Nicholls, C. Analyzing Student Interactions and Meaning Construction in Computer Bulletin Board Discussions. Computers and Education 42: 243-265 (2004).

41. Dewey, J., How We Think: A Restatement of the Relation of Reflective Thinking to the Educative Process, Boston: Heath, 1933.

42. Kim, H., and Bateman, B. Student Participation Patterns in Online Discussion: Incorporating Constructivist Discussion into Online Courses. International Journal on E-Learning 9(1): 79-98 (2010).

43. Moore, J. A Synthesis of Sloan-C Effective Practices. Journal of Asynchronous Learning Networks 16(1): 91-115 (2011).

44. Russo, T. and Benson, S. Learning with Invisible Others: Perceptions of Online Presence and Their Relationship to Cognitive and Affect Learning. Educational Technology and Society 8(1): 5462 (2005).

45. Swan, K., Shen, J, and Hiltz, S. Assessment and Collaboration in Online Learning. Journal for Asynchronous Learning Networks 10(1): 45-62 (2006).

46. Wilson, G., and Stacey, E. Online Interaction Impacts on Learning: Teaching Teachers to Teach Online. Australasian Journal of Educational Technology 20 (1): 33-48 (2004).

47. Beckett, G.H., Amaro-Jimenez, C., and Beckett, K.S. Students' use of asynchronous discussions for academic discourse socialization. Distance Education 31(3): 315-335 (2010).

48. Richardson, J., and Ice, P. Investigating Students' Level of Critical Thinking Across Instructional Strategies in Online Discussions. Internet and Higher Education 13(1/2): $52-59$ (2010). doi:10.1016/j.iheduc.2009.10.009.

49. Skinner, E. Building Knowledge and Community Through Online Discussion. Journal of Geography in Higher Education 31(3): 381-391 (2007). doi:10.1080/03098260601065151.

50. Rex, L.A., Bunn, M., Davila, B.A., Dickinson, H.A., Ford, A.C., Gerben, C., Orzulak, M. M., and Thomson, H. A review of discourse analysis in literacy research: Equitable access. Reading Research Quarterly 45 (1): 94-115 (2010).

51. Waltonen-Moore, S., Stuart, D., Newton, E., Oswald, R., and Varonis, E. From Virtual Strangers to a Cohesive Learning Community: The Evolution of Online Group Development in a Professional Development Course. Journal of Technology and Teacher Education 14(14): 287-311 (2006).

52. Imm, K., and Stylianou, D.A. Talking Mathematically: An Analysis of Discourse Communities. Journal Of Mathematical Behavior 31(1): 130-148 (2012). 
53. Spradley, J.P., The Ethnographic Interview, New York: Holt, Rinehart, and Winston, 1979.

54. Lincoln, Y.S., and Guba, E.B., Naturalistic Inquiry, Beverly Hills: Sage, 1985.

55. Erickson, F., Qualitative Methods in Research on Teaching. In: Wittrock, M.C. (Ed.), Handbook of Research on Teaching, Third Edition,119-161 NY: Macmillan, 1986.

56. Stake, R.E., Case study. In: Nisbet, J. (Ed.), World yearbook of Education, 1985: Research, Policy, and Practice, 277-301, London: Kogan Page, 1985.

57. Hull, D., and Saxon, T. Negotiation of Meaning and Co-construction of Knowledge: An Experimental Analysis of Asynchronous Online Instruction. Computers and Education 52(3): 624639 (2009). doi: 10.1016/j.compedu.2008.11.005

58. Bloom, B., Language development. In: Horowitz, F.D. (Ed.), Review of Child Development Research 4, 245-303. Chicago: University of Chicago Press, 1975.

\section{APPENDIX A: RUBRIC FOR ONLINE DISCUSSIONS: EXPECTED LEVEL OF COMPETENCE*}

\begin{tabular}{|l|l|}
\hline & \multicolumn{1}{|c|}{ Expected Level of Competence } \\
\hline $\begin{array}{l}\text { Content Understanding } \\
\text { (comprehension of the } \\
\text { content under } \\
\text { discussion) }\end{array}$ & $\begin{array}{l}\text { The candidate understands significant ideas relevant to the issue under } \\
\text { discussion. This is indicated by correct use of terminology, precise } \\
\text { selection of the pieces of information required to make a point, correct } \\
\text { and appropriate use of examples and counterexamples, demonstrations } \\
\text { of which distinctions are important to make, and explanations that are } \\
\text { concise and to the point. } \\
\text { Information and knowledge are accurate. } \\
\text { The candidate elaborates statements with accurate explanations, } \\
\text { reasons, or evidence. }\end{array}$ \\
\hline $\begin{array}{l}\text { Reasoning (ability to use } \\
\text { the content to explore an } \\
\text { issue, answer a question, } \\
\text { make a decision, or } \\
\text { discuss a point) }\end{array}$ & $\begin{array}{l}\cdot \text { The candidate actively stimulates and sustains inquiry by asking } \\
\text { thoughtful questions. } \\
\cdot \text { The candidate has a clear idea of the topic under discussion and } \\
\text { sustains inquiry in order to explore relevant issues. } \\
\cdot \text { The candidate stipulates claims or definitions (e.g., "For our } \\
\text { discussion, let's agree that prior knowledge refers to BOTH overall } \\
\text { and specific knowledge."). The candidate realizes when such } \\
\text { stipulations are needed. } \\
\cdot \text { The candidate recognizes values or value conflict as things that form } \\
\text { the assumption basis of arguments and recognizes when it is important } \\
\text { to acknowledge these values. } \\
\cdot \text { The candidate argues by analogy. } \\
\cdot \text { The candidate recognizes the accuracy, logic, relevance, or clarity of } \\
\text { statements. The candidate recognizes contradictions and irrelevant } \\
\text { comments. } \\
\cdot \text { The candidate asks clarifying questions and knows when clarifying } \\
\text { questions need to be asked. } \\
\cdot \text { The candidate distinguishes fact from opinion. } \\
- \text { The candidate summarizes points of agreement and disagreement to } \\
\text { set the stage for further movement; the candidate knows when such } \\
\text { summaries are useful. }\end{array}$ \\
\hline
\end{tabular}




\begin{tabular}{|l|l|}
\hline Interaction with Others & $\begin{array}{l}\cdot \text { The candidate initiates the dialogue with thoughtful and reflective } \\
\text { comments and questions. } \\
\cdot \text { The interactions of the candidate are appropriate for educators in a } \\
\text { graduate setting. } \\
\cdot \text { The candidate invites contributions from others as needed and the } \\
\text { candidate knows when such contributions are needed. } \\
\cdot \text { The candidate acknowledges the statements of others in a way that } \\
\text { builds a consecutive interchange between participants. } \\
\cdot \text { Replies to others are responsive to the statement and indicate that the } \\
\text { candidate understood it and thought about it. } \\
\cdot \text { When disagreeing, the candidate does it respectfully. The nature of } \\
\text { the disagreement is stated and an invitation to respond extended. } \\
\cdot \text { The candidate encourages a variety of points of view. } \\
- \text { The candidate is courteous and attentive } \\
\cdot \text { The candidate is aware of cultural differences in social interactions } \\
\text { and behaves in an appropriate fashion. } \\
\cdot \text { When conflicts arise, the candidate attempts to resolve them. } \\
\cdot \text { The candidate is aware of the value of group input and decision } \\
\text { making. }\end{array}$ \\
\hline
\end{tabular}

*Note: Only the Expected level is given here. The Moving Toward Expected and Not Acceptable levels were removed to shorten the document.

\section{APPENDIX B: EXAMPLES OF APPROPRIATE AND INAPPROPRIATE DISCUSSION BOARD POSTS}

The content and quality of your postings on Blackboard are very important. As I've told you before, much of the power of an online course depends on the active and rich discussions of the participants. In addition to your ability to comprehend the content of the course and to use this understanding as you converse, you are expected to interact with your colleagues in a way that ENCOURAGES discussion. One way to do this is to ask thoughtful questions - those that pull the readers in, that cause people to want to respond, and, most importantly, that end up helping to expand the thinking of those who read your posting. To help you understand what is expected, I have listed two types of responses from past graduate students.

TYPE \#1 - SHORT COMMENTS

"I completely agree with you. I think that some students get stuck in the romance stage and never leave. I'm also still trying to figure out how to get them to move on to the precision stage. You sound like you have a great writing program. How did you get your students to edit their work? ”

"I agree with your explanation of how this theory applies to the writing process. I am interested to learn more about your writing workshop. I teach $1^{\text {st }}$ grade and want to make this year as language rich as possible for the children. Several of my students are learning to write and I would like to extend this. Do you have any suggestions or beginning activities to introduce this?”

Of course you CAN ask your colleagues questions like these: How did you get your students to edit their work? Do you have any suggestions or beginning activities to introduce this? These answers will definitely help YOU with your teaching, and that's an important part of the course too. BUT...the answers do little to help your colleague FURTHER HIS/HER thinking.

TYPE \#2 - LENGTHIER COMMENTS

"You bring up an interesting point. When you write about learning Spanish as a child, you tell of the expectation in your home that family members learn and communicate in Spanish. You were encouraged as a toddler to speak Spanish and you found your needs were met when you did. I wonder if we should 
further consider the effects of family and/or cultural expectations as we think about the stages of Whitehead's Theory of Learning. Many children work hard to please their parents. A large percentage of students go to college whose parents expect them to go. Kids who are told they will be good at math usually are. But what about the flip side: What about children whose families say no one in our family is good at reading? Or math? Or school? People in our family don't go to college. Or don't graduate from high school. Everyone in our family fails at least one grade. I was wondering about this and read an article that gave statistics of low achievers and dropouts. Guess what! Most in these categories are minority groups. The fact is, we need show these students the romance stage of writing - that big picture. They probably won't accept our assurances that being able to write well will help them down the road if that's not what they're learning from home. Can we instill the romance that will be necessary before moving into the precision stage, or is that family/cultural effect too powerful? Maybe we should spend more time working with the parents! What do you think?”

"Your comment about lumping classism and racism together in your thinking made me give more consideration to my own ideas of classism. I suddenly realized I had subconscious notions about classism and had made judgments of people relating to class for a long time- all rather automatically. I searched my teacher's heart to see if I had ever treated a child differently because of classism, and I hope I never have. As I thought about this 'ism” more, I find that it does permeate our society in terms like working class, jet set, blue bloods, oil field trash, white collar, blue collar, old money, new money, and so forth; and if it is present in our society, it will be present in our schools. I started to think about my teaching and how classism affects how I approach lessons. What "big picture" am I giving to these youngsters in my class? I guess it is MY "big picture" - what I believe because of who I am, what I've experienced, what I believe is "right." But, this may not match the "big pictures" of those children. Probably doesn't! How, then can we (mostly middle class teachers) insure that Whitehead does indeed happen in our teaching?"

Do you see the difference in these postings? In the first examples_(Type \#1), you can see the authors are simply chatting, agreeing with their colleagues on some point, and wanting a bit more information. Their questions ask only that their colleagues tell what they already do. Although the questions do encourage their colleagues to write back, those questions don't push the thinking of their colleagues nor take them to a deeper level of reflection.

In the last two examples_(Type \#2), you can see the authors offering a new idea, struggling with issues, showing further research, referring to personal experiences, giving examples to help the reader understand their thinking, and even lamenting a past action. Because of this deeper thinking, questions naturally emerge and these questions challenge their colleagues to think further about the issues too. 